\title{
Inheritance tax regimes: a comparison
}

STEFAN JESTL, Dr.*

Article* $^{* *}$

JEL: D31, H21

https://doi.org/10.3326/pse.45.3.3

\footnotetext{
* This research was financially supported by the Austrian Chamber of Labour (AK). The author would like to thank two anonymous reviewers; Sebastian Leitner; Mario Holzner (wiiw); Miriam Rehm (University of Duisburg-Essen), Matthias Schnetzer (AK) and others for their very helpful comments and suggestions.

${ }^{* *}$ Received: September 7, 2020

Accepted: March 3, 2021
}

\section{Stefan JESTL}

The Vienna Institute for International Economic Studies (wiiw), Rahlgasse 3, 1060 Vienna, Austria e-mail: jestl@wiiw.ac.at ORCiD: 0000-0003-4217-196X 


\section{Abstract}

This paper provides an overview of different inheritance tax regimes in selected European countries and the United States. We show that in the majority of countries the tax rate is related to the relationship between testator and the beneficiary as well as the value of the inherited assets. In most countries the transfer of wealth within families is treated preferentially (lower tax rates, tax exemptions and reliefs). This is particularly the case for business assets and family homes. The analysis further discusses the features and effects of inheritance tax regimes, which include behavioural responses of individuals and different distributional effects of an inheritance tax. Although the actual revenues of inheritance taxation are quite low in the selected countries, some indicators point to higher revenue potentials in the future. An appropriate design for inheritance taxation could further help to decelerate the increase in wealth inequality.

Keywords: inheritance taxation, tax regimes, wealth inequality

\section{INTRODUCTION}

Property taxation is currently an important topic in both politics and economics. The taxation of wealth transfers over generations is particularly controversial. In assessing inheritance taxation, opposition to any such tax is provided by those who prioritise liberal property rights. However, the transfer of wealth may foster wealth inequality, resulting in rising inequality of opportunities. The latter argument provides support for inheritance taxation. In discussing the basic concepts of the tax, Marterbauer and Schürz (2007) distinguish, inter alia, among the equality, justice, and family principles. Following the equality principle, the taxation of inheritance should diminish the intergenerational transmission of inequality and thus at least reduce the growth in the concentration of wealth in family dynasties and upper classes. An inheritance tax thus aspires to achieve a higher level of equality of opportunity within a society. The justice principle suggests that affluent individuals should contribute more to support poorer groups in the society, because they have a higher ability to pay. In contrast, the family principle emphasises the claim of the family in relation to individual property and therefore also its transfer via bequest. The wealth of a deceased individual is considered to be the property of the family and the government is not entitled to intervene. The first two arguments are obviously in opposition to the last in a discussion on the implementation of taxation on inheritance.

The role of family is particularly important for the general attitude towards inheritance taxation (see Fessler and Schürz, 2020). As family values seem to play a dominant role for inheritances and in discussions on its taxation, inheritance taxes are rather unpopular. Fessler and Schürz (2020) claim that even though a relatively large proportion of the Austrian population is in favour of a wealth tax, only a few show any preference for an inheritance tax. Bastani and Waldenström (2021) found that individuals tend not to perceive the part played by inherited wealth in inequality of opportunities. More information about this role increases support for an inheritance tax. The Economist (2017) argues that the negative perception of 
inheritance taxation is related to the secular rise of home-ownership in many countries. Individuals tend to see a higher probability of having to bear the tax.

Against this background, it is surprising that international organisations, such as the OECD and the IMF, have recently called for higher taxation on the wealthy and for shifting from taxes on labour to higher taxes on wealth. By doing so, the potential role of an inheritance tax has been emphasised (see OECD, 2018). The taxation of intergenerational wealth transfers is expected to be less distortive than taxes on labour which would result in beneficial effects for economic growth (see OECD, 2019; Bastani and Waldenström, 2020). This supports the use of an inheritance tax from an efficiency perspective.

Bequests were taxed in all EU member states in 2018, except for Sweden, Latvia, Estonia, Austria, Cyprus and Malta. As outlined by Iara (2015), the design of inheritance taxes across European countries is heterogeneous. Although there are some similarities across countries in the general concept of the tax, we can find differences concerning tax rates and exemptions. In many countries, even when tax rates are progressive, the family principle is still partly considered in the design of inheritance taxation, i.e. close family members are granted preferential treatment.

Differences across countries become also visible when we look at the inheritance taxes as percentage of total taxation in selected European countries in figure 1. As can be seen, the share of inheritance taxes ranges between 0 and $2 \%$ of total taxation. The highest shares can be found in France and the Netherlands, and the lowest in Italy and Denmark.

\section{FigURE 1}

Share of inheritance taxes (as \% of total taxation), 1995-2018

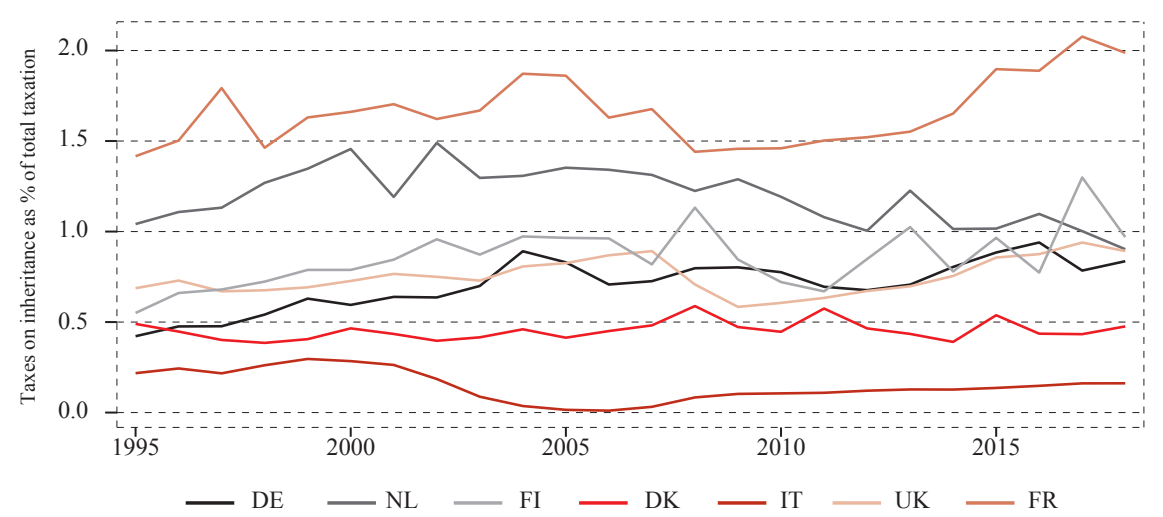

Source: European Commission, DG Taxation and Customs Union, based on Eurostat data; own calculation and illustration.

In the recent past, many European countries have conducted changes and reforms with respect to inheritance taxation. Austria abolished inheritance taxation in 2008. In addition, inheritance taxation was suspended from 2001 to 2006 in Italy. 
Most recently, tax reforms have taken place in Germany and the United Kingdom. Reforms in Germany, enacted in 2017, adapted its existing tax exemptions and reliefs for family businesses. In the United Kingdom, additional exemptions for intergenerational transfer within the family were been introduced. Beyond that, Republicans in the United States have a tax reform plan aimed at abolishing the taxation of inheritances by 2025 (see The Economist, 2017).

This article contributes to the literature by providing an overview of different inheritance tax systems based on a set of selected European countries as well as the US, and by identifying different economic effects emanating from these systems. In doing so, the present article addresses the question of how different inheritance tax systems can affect wealth inequality and which elements of inheritance taxation potentially result in distortionary effects. By drawing on theoretical and empirical research, I discuss implications for the design of the inheritance tax. The analysis predominantly focuses on the current design of inheritance tax systems. For an historical approach to explore the development of inheritance taxation see Beckert (2008) and Henrekson and Waldenström (2016).

I particularly focus on the EU countries Germany, Denmark, Finland, France, Italy, the Netherlands and the United Kingdom as well as on the United States. The selected countries are representative of different inheritance taxation systems. ${ }^{1}$ Moreover, the analysis covers countries where there have recently been discussions on potential reforms of the inheritance taxation system (e.g. Germany and the United Kingdom).

The remainder of this article is as follows. Section 2 discusses the general features of inheritance tax regimes. In section 3, I evaluate the inheritance tax regimes based on a number of criteria. Finally, section 4 concludes.

\section{GENERAL FEATURES OF INHERITANCE TAX REGIMES}

In this section I address the main characteristics of inheritance tax systems across selected European countries and the US. In general, an inheritance tax can be characterised by the following items:

\section{Basis of tax assessment}

Is the tax imposed on the entire legacy or on each legatee separately?

\section{Tax rate design}

What are the determinants of the tax rate?

\section{Exemptions \& reliefs}

What is the general design of exemptions?

- Specific groups of individuals

- Specific treatment of business assets

- Discrimination between asset types.

\footnotetext{
${ }^{1}$ For instance, a double progressivity in tax rates in Germany and the Netherlands; single progressivity in tax rates in the United States and a flat tax in the United Kingdom.
} 
The taxation of intergenerational transfers related to the death of a testator is typically called an inheritance tax. However, one can distinguish between an inheritance tax in the narrow sense and an estate tax in the general sense. In the former case the tax is conceived to be levied on the inheritor, whereas in the latter case the tax is levied on the estate itself (see Nass-Schmidt et al., 2011). An estate tax is common in Anglo-Saxon countries, whereas an inheritance tax in the narrow sense is applied in most European countries (see table 1). However, there are also countries with an inheritance tax composed of both concepts.

\section{TABLE 1}

Inheritance and estate taxes

Inheritance tax (in a narrow sense) Estate tax

DE, DK ${ }^{2)}, \mathrm{NL}, \mathrm{FI}, \mathrm{FR}, \mathrm{IT} \quad \mathrm{DK}^{2)}, \mathrm{UK}, \mathrm{USA}^{1)}$

Note: 1) The US applies an estate tax at the federal level. At the level of individual states, we however find both systems, estate and inheritance tax systems. In our analysis of the US regime we however only consider the federal estate tax. 2) Denmark applies both systems: an estate tax is combined with an inheritance tax (see more details below).

Source: Nass-Schmidt et al. (2011) \& EY (2015); own illustration.

Germany, Finland, France, Italy and the Netherlands impose an inheritance tax in the narrow sense. The United Kingdom applies an estate tax, i.e. the tax is levied on the assets of the deceased person, although the tax is legally called "inheritance tax". Likewise, in the United States an estate tax is imposed on the deceased's estate upon death. Denmark applies both types of inheritance taxation. It levies a tax on the estate and a second one in particular cases (see below) on the individual inheritors.

\subsection{TAX RATE DESIGN}

In order to assess the effects of an inheritance tax, it is important to examine differences in the determinants of tax rates. The two major determinants of the tax rate represent the value of inherited assets as well as the relationship between the testator and the beneficiary. As illustrated in table 2, we can identify four country groups regarding the determinants of the tax rate design.

\section{TABLE 2}

Tax rate design

\begin{tabular}{|c|c|}
\hline Country & Determinants of tax rates \\
\hline IT, DK & Relationship between persons \\
\hline US & Value of (total) inherited assets \\
\hline DE, NL, FI, FR & Relationship between persons \& value of inherited assets \\
\hline UK & None (flat rate) \\
\hline
\end{tabular}

Note: Tax exemptions and reliefs are not considered in the determinants (see below). Source: EY (2015; 2016; 2020); own illustration. 
In Italy and Denmark, the inheritance tax rate depends only on the relationship between the deceased and the recipient of the inherited wealth. In contrast, in the United States, the sole determinant for the inheritance tax rate is the value of the total inherited assets. In addition, in many countries like in Germany, Finland, France and the Netherlands, the tax rate applied depends on both determinants. In the United Kingdom, however, tax rates are irrespective of both which results in a flat rate.

Next, we explore how these two determinants shape the structure of the inheritance tax in the respective countries. According to the relationship between the deceased and the recipient of the inherited assets, we observe different tax classes. Table 3 shows the group of persons in the tax classes within the respective country. In the United States and the United Kingdom, we do not find any tax classes, because tax rates do not depend on the relationship between the deceased and the recipient. This is however different from tax exemptions and reliefs, as in both countries exemptions and reliefs are related to the kinship between the persons involved in the inheritance process (see more details below).

\section{Table 3}

Tax classes

\begin{tabular}{|c|c|}
\hline Country & Class assignments \\
\hline Germany & $\begin{array}{l}\text { I: close relatives }{ }^{1)} \text { (incl. grand-/stepchildren), } \\
\text { II: wider family (incl. siblings), III: others }\end{array}$ \\
\hline Italy & $\begin{array}{l}\text { I: close relatives (incl. grandchildren), II: siblings, } \\
\text { III: other relatives (stepchildren), IV: others }\end{array}$ \\
\hline Netherlands & I: close relatives, II: grandchildren, III: others \\
\hline United Kingdom & - \\
\hline Finland & I: close relatives (incl. grand-/stepchildren), II: all other cases \\
\hline United States & - \\
\hline France & $\begin{array}{l}\text { I: ascendants and descendants, II: siblings, } \\
\text { III: blood relatives (up to fourth degree), IV: others }\end{array}$ \\
\hline Denmark & I: close relatives, II: others \\
\hline
\end{tabular}

Note: 1) close relatives comprise spouses (partner) and children.

Source: EY (2015; 2016; 2020); own illustration.

Table 4 provides, at a glance, inheritance tax rates applied in our country sample. As shown in table 3 , the consideration of the relationship between persons allows for the definition of different tax classes. Next to that, the asset as a tax rate determinant implies the possibility of imposing a varying tax rate depending on the value of the inherited assets. In countries where both determinants are implemented, we find increasing average tax rates within and across tax classes. Obviously, closer relatives generally face a relatively lower tax rate. The treatment of spouse or partner, in particular, and of other direct relatives, reveals tax privileges. This implies higher marginal tax rates in higher tax classes. This is often referred to as "double progressivity". On the one hand there is a progressivity in the tax rates across the tax classes and on the other hand there is one within the respective classes. Thus, again not surprisingly, the extent of the progressivity in the tax rates 
is strongly related to the determinants of tax rates discussed above. As expected, we observe the lowest variation in the tax rates in the United Kingdom. In Denmark, the first tax class refers to the estate tax that is levied on the inherited wealth. When inheritors are not family members, an inheritance tax is imposed additionally on the inheritor, whereby the total tax rate then yields $36.25 \%$. In contrast, family members have to pay only the estate tax of $15 \%$.

TABLE 4

Tax rate groups

\begin{tabular}{|c|c|}
\hline Country & Tax rates \\
\hline Germany & $\begin{array}{l}\text { Tax classes with different progressivity - I: } 7-30 \% \text {, } \\
\text { II: } 15 \%-43 \% \text {, III: } 30-50 \%\end{array}$ \\
\hline Italy ${ }^{1)}$ & Tax classes with fixed rates - I: $4 \%$, II: $6 \%$, III: $6 \%$, IV: $8 \%$ \\
\hline Netherlands & $\begin{array}{l}\text { Tax classes with different progressivity - I: } 10 \%-20 \% \text {, } \\
\text { II: } 18 \%-36 \% \text {, III: } 30 \%-40 \%\end{array}$ \\
\hline United Kingdom ${ }^{2}$ & $40 \%$ \\
\hline Finland & Tax classes with different progressivity - I: 7-19\%, II: $19-33 \%$ \\
\hline United States & Class with progressivity $-18-40 \%$ \\
\hline France & $\begin{array}{l}\text { Tax classes with different progressivity - I: } 5-45 \% \text {, II: } 35-45 \% \text {, } \\
\text { III: } 55 \% \text {, IV: } 60 \%\end{array}$ \\
\hline Denmark & Tax classes with fixed rates - I: $15 \%$, II: $36.25 \%$ \\
\hline
\end{tabular}

Notes: 1) Class II contains tax-free amount tax, whereas class III does not have it. 2) The tax rate can be reduced in case of leaving $10 \%$ of estate to charity.

Source: EY (2015; 2016; 2020); own illustration.

\subsection{EXEMPTIONS AND RELIEFS}

Inheritance tax systems can also be classified according to their exemptions and reliefs. In principle, tax exemptions and reliefs allow the reduction of the tax base and subsequently the tax burden. This section addresses inheritance tax exemptions and reliefs with respect to specific groups of individuals and specific treatment of business assets, as well as discrimination between asset types.

\subsubsection{SPECIFIC GROUPS OF INDIVIDUALS}

Countries where the relationship between the testator and the beneficiary is considered in the design of the inheritance tax are generally characterised by a system of different tax-free thresholds. For example, in Germany we even find different tax-free amounts within these classes.

The pattern of the tax-free amounts corresponds largely to the structure of the tax classes in tables 3 and 4 . The closer the relatives, the lower the tax rate and the higher the tax-free amounts. Furthermore, the tax-free amount is little or nothing when deceased and heir are not related. A common characteristic in nearly all our selected countries is that the spouse/partner can receive the inheritance tax-free. This is even the case in countries where the relationship between persons is actually not considered in the tax rate design, as in the United States and the United Kingdom. An exemption to this is Italy, where the spouse is not exempted from tax. 
However, individuals in the first tax class can make use of an exemption amount of EUR 1 million. In the United States and the United Kingdom, we find uniform taxfree amounts. As discussed above, however, there are additional tax-fee amounts for related heirs even in these countries. In the United States, the uniform tax amount covers wealth assets of USD 11 million and is called "unified tax credit". Beyond that, transfers to spouses can be entirely excepted from taxation. In the United Kingdom, the uniform tax-free amount is only $£ 325,000$, but can however be extended for close family members. Further special cases are Denmark, the Netherlands and Finland, where even the state can benefit from exemptions.

\section{TABLE 5}

General exemptions and reliefs

\begin{tabular}{|c|c|}
\hline Country & Exemptions and reliefs \\
\hline Germany & $\begin{array}{l}\text { Different tax-free amounts within classes depending on degree } \\
\text { of kinship, decreasing tax-free amounts across classes, family } \\
\text { home for spouse as well as children and stepchildren }\end{array}$ \\
\hline Netherlands & $\begin{array}{l}\text { Different tax-free amounts depending on degree of kinship, } \\
\text { special exemptions for disabled persons and the state }\end{array}$ \\
\hline United Kingdom & $\begin{array}{l}\text { Uniform tax-free amount additional tax-free amount for close } \\
\text { family members transfer to spouse/civil partner is tax-free }\end{array}$ \\
\hline Finland & $\begin{array}{l}\text { Exemptions for the state and its institutions, special public } \\
\text { employees (e.g. diplomats), exemption for spouse possible }\end{array}$ \\
\hline United States & $\begin{array}{l}\text { High tax-free amount, unlimited deduction for spouses that are } \\
\text { US citizens, deduction for non-US citizen spouse limited }\end{array}$ \\
\hline France & $\begin{array}{l}\text { Different tax-free amount across tax classes, transfer to spouse } \\
\text { is tax-free }\end{array}$ \\
\hline Denmark & $\begin{array}{l}\text { Exemption for transfers to spouse or an organisation of public } \\
\text { utility as well as state }\end{array}$ \\
\hline Italy & $\begin{array}{l}\text { Different tax-free amounts across classes, no tax-exempt threshold } \\
\text { for other relatives (stepchildren) and others (III \& IV), special } \\
\text { exemptions for disabled persons }\end{array}$ \\
\hline
\end{tabular}

Source: EY (2015; 2016; 2020); own illustration.

\subsubsection{SPECIFIC TREATMENT OF BUSINESS ASSETS}

The preferential treatment of family businesses and businesses in general is a debated central theme, and was so particularly in the discussion on the most recent reform of the German inheritance tax regime. The main argument for preferential treatment suggests that the taxation of such transfers may lead to liquidity problems of firms and subsequently to liquidations (see Bräutigam et al., 2017). Moreover, preferential treatment of (family) businesses may further foster firm-specific investments and allow a long-term planning and focus of the businesses (see Wiebe and Fetzer, 2015). Thus, it is beneficial for the economy to dampen the inheritance tax burden on (family) businesses (see Beznoska, Hentze and Stockhausen, 2020). In 23 out of 28 EU member states we find exemptions or special reliefs for intergenerational transfer between family and closely held businesses

\footnotetext{
${ }^{2}$ The unified tax credit was increased from USD 5 million to USD 11 million under President Donald Trump.
} 
upon death. The countries without an exemption or special relief are Bulgaria, Denmark, Luxembourg, Lithuania and Slovenia. Furthermore, the United States does not assign separate tax privileges to family or closely held businesses. This might be related to the generally high tax-free amount ("unified tax credit"). In some countries, the exemptions only refer to transfers of businesses where the prospective testator acts as an entrepreneur and/or the deceased must own the business a certain period of time before death. For example, the latter constitutes a prerequisite for tax relief in the United Kingdom. In addition, the inheritor needs to continue the business after the receipt at least for a specific period of time in some countries (e.g. Italy, Netherlands). Beyond that, tax exemptions and reliefs for businesses may principally favour a typical sort of legal form, insofar as family businesses as well as business partnerships are preferred as compared to corporate enterprises (see OECD, 2016). In general, the preferential treatment of businesses might be associated with strategic tax planning, as there is an incentive to convert non-business assets to business assets (see Beznoska, Hentze and Stockhausen, 2020) (see more details below).

In Germany, the exemptions with respect to business transfers are not restricted to a specific tax class and thus are independent of the relationship between testator and beneficiary. In general, these exemptions and tax reliefs are clearly aimed at supporting the continuity of the business across generations. Potential negative impacts of an inheritance tax on business activities are addressed by Astrachan and Tutterow (1996). They point to negative impacts on corporate investment decisions of inheritance taxation, which may limit entrepreneurial growth. Likewise, Brunetti (2006) explored the impact of the estate tax on business sales by using probate records for San Francisco. The estimation results suggest a positive effect of taxation on business sales. In contrast, Houben and Maiterth (2011) drew on data from German inheritance tax statistics as well as SOEP data and compared the German inheritance tax system with the former system with respect to privileges for bequeathed businesses. The former tax system generally allowed privileges to a lower extent. They concluded that there is no need for inheritance tax exemptions and reliefs for businesses in order to support the business continuation. Similarly, the German Bundesministerium der Finanzen (2011) argues that inheritance tax relief in Germany is designed improperly to protect businesses. In 2016, a tax reform took place in Germany concerning the intergenerational transfer of businesses. Stricter regulations for business transfers were enacted as well as the reduction of tax-free amounts in the case of enterprise values exceeding a certain threshold. However, the preferential treatment of family businesses is still criticised after the reform. The exemptions still constitute a complex system, in which discrimination among asset types prevails (see Brauns and Schuler, 2016).

\subsubsection{DISCRIMINATION AMONG ASSET TYPES}

Finally, we find discrimination among specific asset types. In this respect, the bequest of family homes receives a preferential tax treatment in some countries. For example, in the United Kingdom a high tax-free amount is deductible if the 
inherited family home is transferred to the children. Likewise, a higher tax-free amount for family homes is applied to relatives in class I in Germany. Specifically, the family house is completely tax-free for spouses/partners if they dwell in it. In addition, agricultural and forestry assets are treated preferentially with respect to inheritance taxation in some countries (e.g. Germany, France).

\section{EVALUATION OF INHERITANCE TAX SYSTEMS}

In order to compare systems of inheritance taxation, we need to evaluate the tax according to meaningful criteria. Brunner (2014) generally argues for criteria such as potential revenues, potential costs and distributional effects to evaluate an inheritance tax. In addition, Schratzenstaller $(2013 ; 2015)$ suggests a list of evaluation criteria to assess and compare different property taxes. In the following we compare the inheritance tax regimes of our selection of countries applying the following criteria:

\section{Individual's response to inheritance and inheritance taxation}

Are there (un)favourable responses of individuals to the receipt of the inheritance as well as the imposition of the inheritance taxation? How do they occur in the different inheritance tax systems?

\section{Distributional effects / Accuracy of taxation}

What is the distributional impact of inheritance taxation? What are the differences concerning distributional effects among inheritance tax regimes across countries?

\section{Actual tax revenue and potentials}

How does the actual tax revenue differ among countries and what is the revenue potential of inheritance taxation?

\subsection{INDIVIDUAL'S RESPONSE TO INHERITANCE TAXATION AND INHERITANCE} In general, an inheritance tax is regarded as growth-compatible. Since the time of the intergenerational transfer is generally unknown, individuals' reactions to an inheritance tax seem to be limited (see Arnold et al., 2011). However, responses in the individual's behaviour cannot be completely precluded. The literature distinguishes between responses in the behaviour of the prospective decedents and the heirs. In general, reactions might be changes in savings behaviour as well as in wealth accumulation behaviour. The tax might even result in the emigration of prospective testators and potential heirs (see Schratzenstaller, 2013). In this respect, Bakija and Slemond (2004) analysed migration behaviour of rich individuals due to changes in estate taxation, using data for the United States from 1965 to 1998 . The results suggest that although there were some movements of rich to regions with lower estate taxes, the numbers were only small. They further underline negative net effects on tax revenues. The negative effect due to the tax reduction in a region could not be offset by the influx of richer individuals to this particular region. In a similar vein, Conway and Rork (2006) explored the 
migration responses of the elderly due to estate tax policies in the US. They do not find evidence that estate tax policies affect the migratory behaviour of the elderly.

\subsubsection{POTENTIAL RESPONSES OF PROSPECTIVE DECEDENT ON INHERITANCE} TAXATION

The response in the behaviour of the prospective decedent is mainly determined by the bequest motive (see Cremer and Pestieau, 2011). These behavioural responses are mostly modelled and analysed in a theoretical framework while empirical evidence is scarce (for an overview of analysis done, see Kopczuk, $2013 \mathrm{~b}$ ). Whether the disposition of an estate is related to a specific motive, such as altruism, the joy of giving or some strategic purpose, an inheritance tax is supposed to have an impact on the decedent's behaviour, potentially resulting in changes in consumption as well as saving behaviour (see Kopczuk and Slemrod, 2001). Since these motives are strongly focused on the family, we can expect stronger behavioural changes when the recipients are closer relatives. In this regard, lower tax rates as well as tax exemptions for close relatives could dampen such an effect (see Cremer and Pestieau, 2011). Thus, this relationship favours inheritance tax systems where the relationship between persons is considered.

Moreover, the behavioural responses of the prospective decedent might be related to tax planning in order to minimise and avoid a high tax burden. Such reactions can typically affect the timing and the value of the prospective inherited wealth. Tax planning is therefore likely to have repercussions on tax revenues (see Beznoska, Hentze and Stockhausen, 2020). Kopczuk (2007) investigated the behaviour of donors that suffered from a severe illness prior to death in the United States. He finds evidence for tax planning, as donors significantly reduced the value of the reported wealth in tax returns. Kopczuk and Slemond (2003) provide further support for the prevalence of tax planning by donors. In contrast, Sommer (2017) analysed wealth transfers by exploiting administrative data for Germany and did not find evidence for tax planning in the case of inheritances. Moreover, differences in taxes and exemptions between inheritance and inter-vivo gifts may provide an incentive to transfer wealth before death (e.g. see Sommer, 2017). Beznoska, Hentze and Stockhausen (2020) discuss the preferential treatment of inter-vivo gifts as opposed to inheritances in Germany. This also refers to transfers of family businesses (see below). Kopczuk (2007) however shows that wealthy individuals tend to prefer to hold their assets until death and are reluctant to transfer wealth while alive.

Under a tax system where the degree of the relationship between testator and their influences the actual tax burden, tax avoidance might be more common. As we have already discussed, the tax can be principally levied on the total property of the decedent or on the inherited assets received by individual recipients. Thus, testators could lower the tax burden by allocating the bequest to a larger number of recipients in the case of an inheritance tax in the narrow sense.

In addition, inheritance tax exemptions and reliefs for business assets may affect the behaviour of the prospective decedent. In this respect, tax privileges may 
divert investments towards certain business assets or influence the choice of the legal form of businesses, even though these options are less productive. Such inefficient tax planning activities can therefore cause a misallocation of capital. Furthermore, an inheritance tax privilege for family businesses may result in lower managerial quality, since the pool of potential managers is restricted to the managerial ability of family members (see Andrews and Westmore, 2014). Thus, tax privileges for family businesses are likely to result in lock-in effects which prevent the reallocation of capital (see OECD, 2016) and may induce biased investment decisions (see Bundesministerium der Finanzen, 2012).

\subsubsection{POTENTIAL RESPONSES OF HEIRS TO PROSPECTIVE INHERITANCES}

Furthermore, the literature discusses the potential behavioural responses of heirs to future inheritances. Not only the actual receipt, but even the expectation of an inheritance may already influence the behaviour of (potential) heirs. ${ }^{3}$ The direct behavioural change of inheritance receipt is discussed by Holtz-Eakin, Joulfaian and Rosen (1993) pointing to reduced tax revenues due to the so-called "Carnegie effect". This describes the observable reduction in labour supply after the transfer, triggered by an increased capability to consume. There are three determinants for the magnitude of this effect: fixed costs of adjustment (i.e. cost for reduction in labour supply), age and family structure. The higher the amount of inherited wealth, the stronger the "Carnegie effect", since the fixed costs of adjustment are already covered. The magnitude of the effect correlates positively with the age of the recipient. Older individuals tend to react more sensitively to inherited assets, especially when they have high alternative income sources in non-work alternatives (e.g. early retirement schemes). Moreover, heirs without children ${ }^{4}$ and non-related heirs tend to respond with stronger reductions in labour supply. Bø, Halvorsen and Thoresen (2019) provide evidence for stronger adverse labour supply effects of the "Carnegie effect" for older individuals, non-related heirs and individuals who received higher amounts of wealth by using Norwegian administrative register data. They conclude that progressive tax rates in general as well as the higher tax burdens of non-relatives can mitigate the "Carnegie effect". This again favours an inheritance tax system where the relationship between persons is implemented. Similarly, Kopczuk (2013a) argues that an inheritance tax is preferable to an estate tax, since it can influence the distortionary behaviour of heirs to a larger extent.

Moreover, Elinder, Erixson and Waldenström (2018) emphasise the role of different saving and consumption propensities across the wealth distribution. By using population-wide register data for Sweden, they found evidence that households at the lower part of the wealth distribution steadily consume more out of the inherited wealth over time. This further has implications on the evolution over time of wealth inequality (see below).

\footnotetext{
${ }^{3}$ From a theoretical point of view, in case of a completely foreseen inheritance the behaviour has already been adjusted before the inheritance is actually received.

${ }^{4}$ Doorley and Pestel (2020) find strong adverse labour market effects for households that received an inheritance and did not have children using German data.
} 
The intergenerational transfer of wealth seems to play a major role in the accumulation of wealth as well as in wealth inequality. A number of empirical findings suggest that bequests exert a stronger influence on wealth accumulation than earned income (see Leitner, 2016; Humer, Moser and Schnetzer, 2015, 2016; and Fessler and Schürz, 2018). ${ }^{5}$ Adermon, Lindahl and Waldenström (2018) investigate the correlation between the wealth of parents and children by exploiting information about four generations in Sweden. Their results suggest that bequests and gifts account for a large part of the parent-child wealth correlation. Thus, one of the main arguments for an inheritance tax is its potential equalising effect on the wealth distribution within a generation of heirs. However, the magnitude of the inequality-reducing effect of an inheritance tax depends crucially on the ability to levy the tax on wealthy individuals. Since wealth is typically highly concentrated, the accuracy of the taxation seems to be fulfilled. Moreover, the accuracy of an inheritance tax is more pronounced, the higher the tax-free amount and the more progressive the tax rate (see Schratzenstaller, 2013).

As discussed above, inheritance tax systems can, inter alia, be characterised by the tax rate design as well as tax exemptions and reliefs. The tax rate design is typically determined by the relationship between the decedent and the recipient and/or the value of the assets. If a progressive tax rate is applied, the distributional effect of inheritance taxation can be increased. In contrast, the consideration of the relationship between persons only (see Italy and Denmark in table 2) allows different fixed tax rates across tax classes. In this case, the distributional effect is totally limited to the kinship between the persons involved in the inheritance process. A combination of both determinants, however, means distinct average tax rates across and within groups. In those inheritance tax systems, we thus find a double progressivity. When intergenerational transfers mainly occur within the close family, there is a lower progressivity in the tax rates in addition to a lower general tax level, limiting the equalising effect even further.

Tax exemptions are closely related to the determinants of the inheritance tax design. In countries where the relationship between individuals is irrelevant for the tax rate design, there are tax exemptions which apply to all individuals. In general, tax-free amounts are usually higher for close relatives. The spouse/partner in particular enjoys a higher tax-free amount or pays no tax, even in systems with an estate tax. Although higher tax-free amounts imply a higher progressivity in taxation, tax exemptions induce a weaker distributional effect when intergenerational transfers occur mainly within the close family. The generosity of high tax exemptions for close relatives is expected to reduce the distributional effect of an inheritance tax.

Moreover, the basis of tax assessment might have an impact on wealth distribution. There is an incentive to divide the inheritance and allocate the wealth to a

${ }^{5}$ There are also studies that find a less important role of inheritances for wealth accumulation (for instance, see Beznoska, Niehues and Stockhausen, 2018). 
larger number of individuals when the tax is levied on the recipients. With a number of children, the inherited wealth would be broader distributed resulting in an equalising effect (e.g. see Atkinson and Harrison, 1978), especially in the case of highly-concentrated wealth at the top.

In order to assess the distributional effect of inheritances, Karagiannaki (2017) and Bönke, van Werder and Westermeier (2017) compared wealth distribution with bequests to wealth distribution without bequests. Like most other studies that apply this comparison, they find a reduction in the relative wealth inequality, although the absolute wealth inequality increases. Inheritances are relatively more important for the accumulation of wealth for less wealthy households than richer ones. ${ }^{6}$ This approach, however, assumes that the total inherited wealth is saved and thus increases the wealth stock of individuals and households. Differences in the saving as well as consumption behaviour across the wealth distribution may however result in diverging outcomes (see Elinder, Erixson and Waldenström, 2018). In principle, a higher marginal propensity to consume reduces the wealth stock over time. The direction of the distributional effect depends on the actual marginal propensities to save and to consume across the wealth distribution. Karagiannaki (2017) provides evidence that households at the lower part of the wealth distribution tend to reveal a higher propensity to consume out of the inherited wealth. Elinder, Erixson and Waldenström (2018) further argue that wealthier heirs are likely to receive higher returns on wealth. Thus, wealth inequality is assumed to increase steadily over time after the wealth transfer.

Empirical results for the direct effect of inheritance taxation on wealth inequality are rather scarce. Elinder, Erixson and Waldenström (2018) provide first insights into this nexus drawing on population register data on inheritances and wealth in Sweden. ${ }^{7}$ Interestingly, their results suggest that the inheritance taxation has a small (short-run) disequalising effect on wealth inequality, as wealthier heirs generally pay more taxes in absolute terms but less in relative terms compared to less wealthier heirs. Elinder, Erixson and Waldenström (2018) however further find that the inheritance tax may increase equality, when inheritance tax revenues are used for redistribution measures. Accordingly, there might be an overall inequality-reducing effect.

\subsection{TAX REVENUE POTENTIALS}

The main determinants of the potential revenue of an inheritance tax regime are the definition of the inheritance tax base including exemptions and the dynamics of inheritance flows, behavioural responses of concerned individuals and the explicit tax rate design. A progressive tax rate generally implies a high tax revenue

\footnotetext{
${ }^{6}$ The equalising effect of inherited wealth is also supported by findings of Elinder, Erixson and Waldenström (2018), Boserup, Kopczuk and Kreiner (2016) and Wolff and Gittleman (2014).

${ }^{7}$ Sweden abolished the taxation of inherited wealth in 2004. Inheritance taxes in Sweden previously depended on the relationship between the deceased and the heir as well as the value of the inherited wealth (for more details see Henrekson and Waldenström, 2016).
} 
potential, especially in the context of highly concentrated wealth. However, when the design of the tax rates also considers the relationship between beneficiary and decedent, the progressivity and tax revenue potential are likely to be reduced. Moreover, tax exemptions influence the tax base und thus the potential revenue. In the case of an inheritance tax the testator may lower the prospective tax burden by allocating the bequest to a larger number of recipients. This might also result in a bias towards lower tax revenues as compared to an estate tax. Tax planning may also arise due to differences between inheritance and gift taxation, insofar as effective gift taxes can generally be lower than effective inheritance taxes (see Beznoska, Hentze and Stockhausen, 2020; Sommer, 2017). This can also have negative repercussions on tax revenues.

In order to shed light on differences in revenues of inheritance tax systems, we shall compare the tax income of selected countries as percentage of GDP over time. Obviously, in various countries there have been significant reforms in the inheritance tax regimes in operation, resulting in considerable changes of revenue potentials.

Figure 2 illustrates the evolution of inheritance and estate tax revenues in Finland, the Netherlands, Germany, France, the United Kingdom and the United States from 1965 to 2015 (US data for the estate tax are available only for 1970-1989 from the OECD, thereafter estate and gift tax is provided combined). In general, tax revenues are quite small, ranging between 0.05 and $1 \%$ of GDP. The inheritance tax system in Finland, the Netherlands, France and Germany is characterised by a double progressivity (see tables 3 and 4), whereas a uniform flat rate is applied in the United Kingdom and a progressive rate based on asset value only, in the United States. Both in the United States and the United Kingdom liberal tax reforms had resulted in sharp drops in revenues by the end of the 1980s. In general, tax exemptions and reliefs can have a substantial effect on the effective inheritance/estate tax. A large increase in exemptions and reliefs reduces the effective tax rate and thus tax revenues. In those countries applying double progressivity we observe an increasing trend in the revenue (relative to GDP) while there are almost constant revenues in the United Kingdom. In 2015, France, Finland and the Netherlands exhibit the highest inheritance tax revenues in our country sample. Their tax regimes are characterised by a strong progressivity across tax classes (see table 4). This simple descriptive comparison between countries suggests that inheritance tax systems with a double progressivity tend to result in higher tax revenues over time than differently designed regimes. However, the actual tax revenue in the US and the United Kingdom also ranges at a high level.

The overall low rates of tax revenues are often used as an argument against inheritance taxation (see Brunner, 2014). However, since the overall wealth stock tends to increase in the long-run, an inheritance tax possesses a high tax revenue potential (see Schratzenstaller, 2013). Even when the tax-free amount is high, there are still tax revenue potentials due to the concentration of wealth (see Bach, 2016; Humer, 2014). 
Figure 3 presents the net private wealth to net national income ratio for our group of selected countries. The ratio has continuously increased in all countries since the 1990s. This implies that private wealth stocks have risen faster than GDP in these countries indicating a rising tax potential. The highest ratio is found in Italy, followed by the United Kingdom and France.

\section{Figure 2}

Inheritance and estate tax revenues (as \% of GDP) in FI, NL, DE, FR, US and UK, 1965-2010
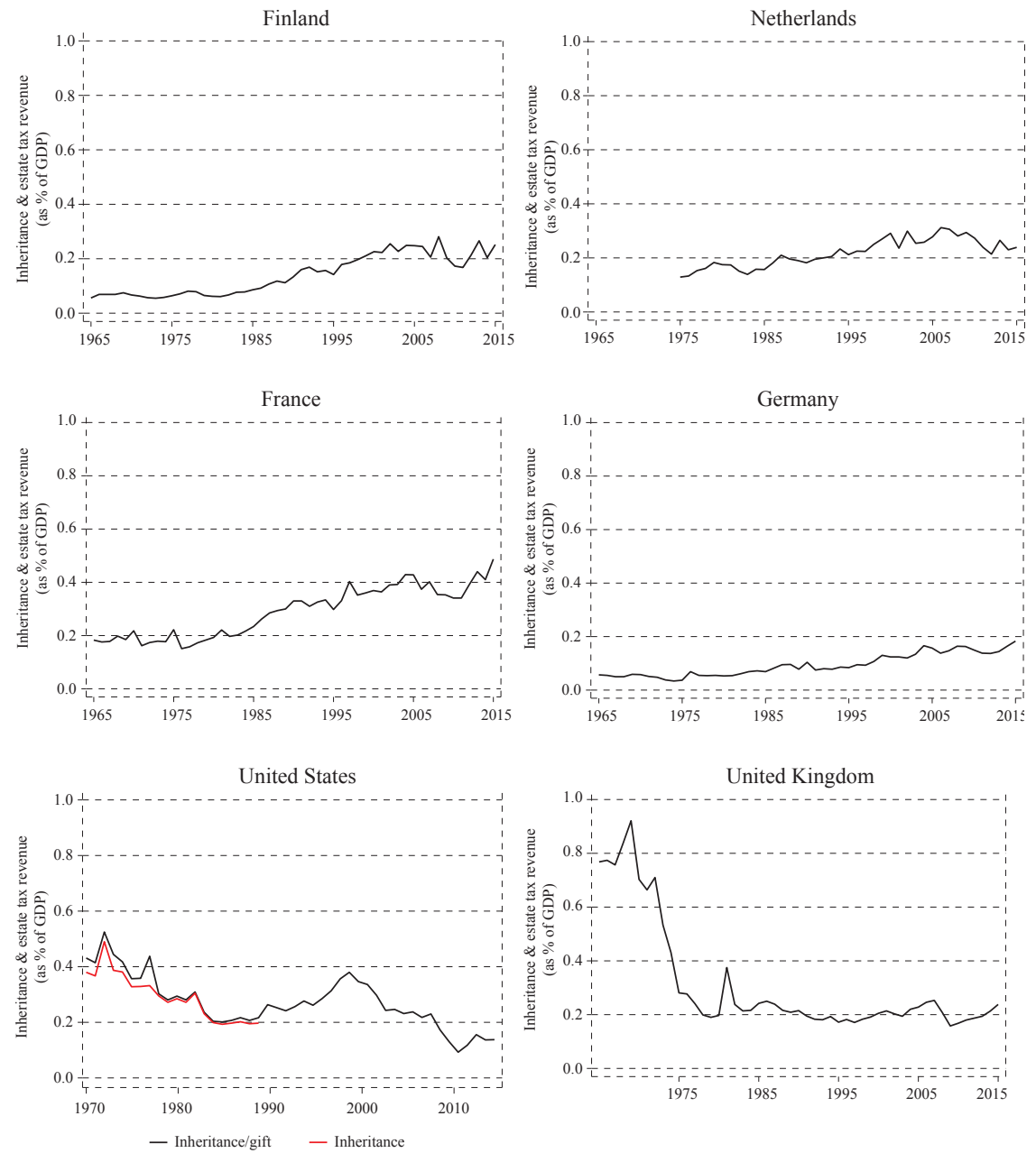

Source: OECD database, own illustration. 


\section{Figure 3}

Net private wealth to net national income ratio, 1955-2015

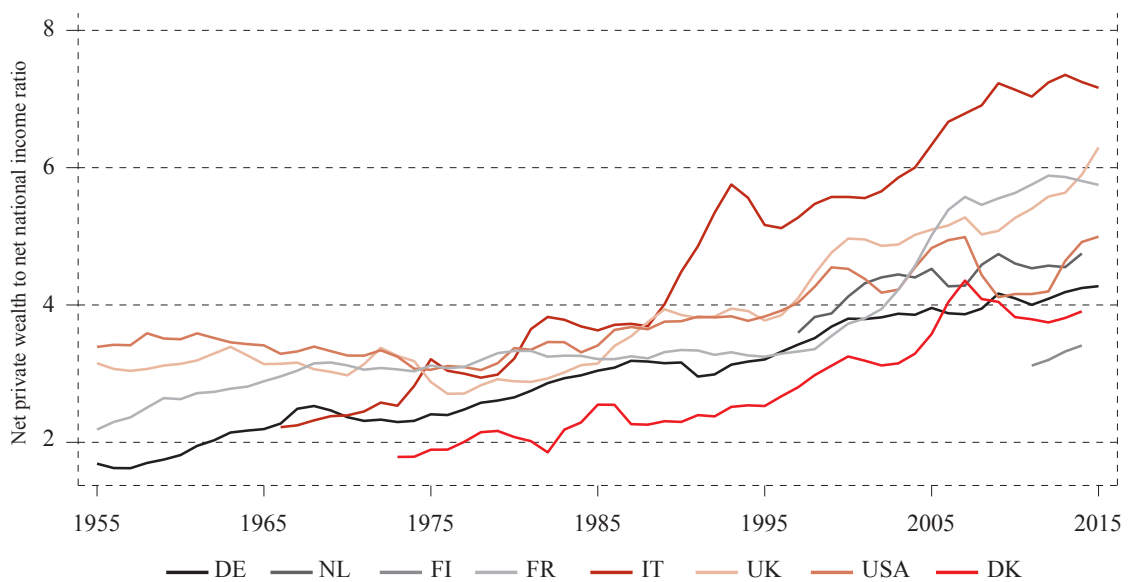

Source: World Wealth and Income Database (WID), own illustration.

\section{Figure 4}

Wealth-income ratio versus inheritance tax revenue (as \% of GDP), 1965-2015
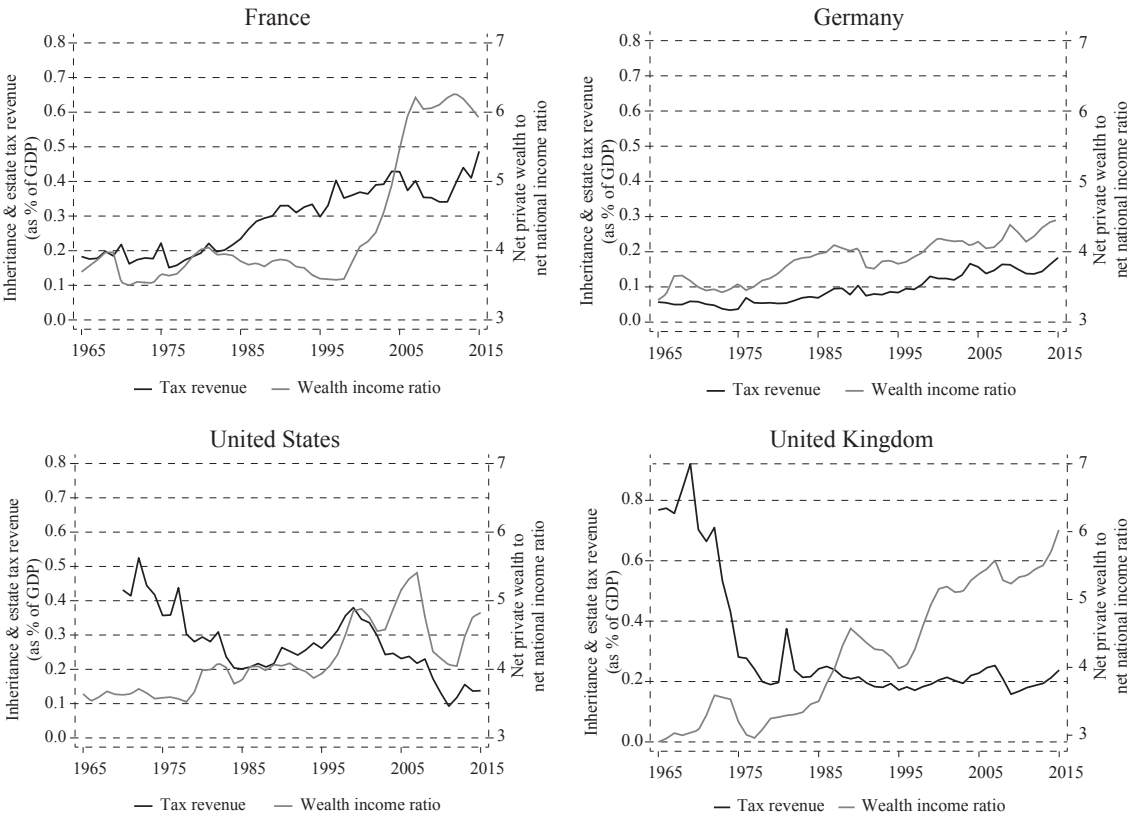

Source: World Wealth and Income Database (WID) \& OECD database, own illustration.

Moreover, in figure 4 we compare the actual inheritance tax revenue ${ }^{8}$ and the corresponding potential approached by the net private wealth to net national income

\footnotetext{
${ }^{8}$ For the US, we consider the inheritance and estate tax as well as the gift tax revenues combined.
} 
ratio for France, Germany, the United States and the United Kingdom. ${ }^{9}$ These countries are generally characterised by different tax rate designs (see tables 3 and 4). France and Germany apply a double progressivity in the tax rate system, whereas the United States only considers the value of inherited assets as a determinant for tax rates. In contrast, we find none of the discussed determinants in the tax rate system of the United Kingdom. As can be seen, we find similar paths for both, revenues and the wealth-income ratio, in France and Germany. This simple descriptive comparison suggests that the French and German inheritance tax systems seem to make use of the growing potential accruing from the rising wealth-income ratio. ${ }^{10}$ In contrast, the regimes applied by the United Kingdom and the United States seem to not to exploit the increased wealth stock. As already discussed above, this might be related to higher tax exemptions and reliefs that lower the effective tax rates.

\section{CONCLUSION}

The taxation of intergenerational transfers is a much-debated topic in the public discourse. One of the main arguments against an inheritance tax refers to the claim of the family in relation to the individual property and therefore also to intergenerational transfers. The wealth accumulated over generations is the property of the family and the government is not entitled to intervene. By contrast, the basic principles of taxation suggest that individuals should be charged according to their ability to pay. Therefore, affluent individuals should contribute more in order to finance public goods. In addition, intergenerational transfers influence wealth inequality within a society and substantially determine the level of the equality of opportunity.

The analysis presented in this paper addresses differences in the design of inheritance taxation across selected European countries and the United States. In general, the main determinants in the design of the inheritance tax consider the relationship between testators and inheritors as well as the progressivity depending on the value of the inheritance. Most of our selected countries apply both in their taxation design. Intergenerational transfers within the family are in general treated preferentially; graduated tax-free amounts and exemptions are common, as are progressive tax rates. Exemptions for family businesses however often result in negative incentives for investment decisions and could thus be detrimental to economic growth. Alternatively, the taxation of intergenerational transfers of businesses could be linked to tax deferral in order to mitigate the tax burden (see OECD, 2016).

In general, it is difficult to assess the total distributional effects which result from different regimes of inheritance taxation. The overall effect is determined by the design of the tax rate, tax exemptions and reliefs (affecting the effective tax rate), the individual's behaviour as well as the actual wealth concentration. However, since we can expect a further increase in the total wealth stock and its concentration over time, an inheritance tax appears to burden wealthier households and thus

\footnotetext{
${ }^{9}$ Due to data limitations, we cannot show graphs for Italy, Denmark, Finland and the Netherlands.

${ }^{10}$ Here, the implicit assumption is that the wealth distribution across age cohorts is similar across countries. This implies that the probability of observing an inheritance is also similar across countries.
} 
foster the ability-to-pay principle of taxation. In cases in which intergenerational transfers occur within close kinship and wealth accumulation therefore operates in a self-reinforcing way within family dynasties, taxes are levied predominantly on wealthier households. In such cases, inheritance taxation can have an equalising effect. This argument supports a strong progressivity in tax rates depending on the value of the inherited assets combined with a higher tax-free amount.

Thus, an inheritance taxation rate design should incorporate a preferential treatment of family members and consider at the same time the higher ability to pay of wealthier individuals. The consideration of both arguments in a taxation system may also improve the justification of the inheritance taxation within a society (for the role of family values for the attitude towards an inheritance tax see Fessler and Schürz, 2020). A system including, on the one hand, progressivity of tax rates depending on kinship, and on the other hand, high progressivity depending on the value of inherited wealth, seems to be appropriate to fulfil these requirements. Exemptions for family homes and tax-free amounts for family members can further foster the acceptance of an inheritance tax. Tax-free amounts however have to be limited (see OECD, 2018) in order to mitigate negative effects on tax revenues. Moreover, differences between gift and inheritance taxation should be avoided to limit incentives for tax planning.

\section{Disclosure statement}

No potential conflict of interest was reported by the author. 
1. Adermon, A., Lindahl, M. and Waldenström, D., 2018. Intergenerational wealth mobility and the role of inheritance: Evidence from multiple generations. The Economic Journal, 128(612), pp. 482-513. https://doi.org/10.1111/ecoj.12535

2. Andrews, D. and Westmore, B., 2014. Managerial Capital and Business R\&D as Enablers of Productivity Convergence. OECD Economics Department Working Papers, No. 1137. https://doi.org/10.1787/5jxx3d441knr-en

3. Arnold, J. M. [et al.], 2011. Policy for Economic Recovery and Growth. The Economic Journal, 121(550), pp. 59-80. https://doi.org/10.1111/j.1468-0297. 2010.02415.x

4. Astrachan, J. H. and Tutterow, R., 1996. The effect of estate taxes on family business: Survey results. Family Business Review, 9(3), pp. 303-314. https:// doi.org/10.1111/j.1741-6248.1996.00303.x

5. Atkinson, A. B. and Harrison, A. J., 1978. Distribution of personal wealth in Britain. Cambridge: Cambridge University Press.

6. Bach, S., 2016. Erbschaftsteuer, Vermögensteuer oder Kapitaleinkommensteuer: Wie sollen hohe Vermögen stärker besteuert werden? Discussion Papers, No. 1619. https://doi.org/10.2139/ssrn.2871833

7. Bakija, J. and Slemrod, J., 2004. Do the rich flee from high state taxes? Evidence from federal estate tax returns. NBER Working Paper, No. 10645. https://doi.org/10.3386/w10645

8. Bastani, S. and Waldenström, D., 2020. How Should Capital Be Taxed? Journal of Economic Surveys, 34(4), pp. 812-846. https://doi.org/10.1111/joes.12380

9. Bastani, S. and Waldenström, D., 2021. Perceptions of inherited wealth and the support for inheritance taxation. Economica. https://doi.org/10.1111/ecca.12359

10. Beckert, J., 2008. Inherited wealth. Princeton: Princeton University Press.

11. Beznoska, M., Hentze, T. and Stockhausen, M., 2020. The inheritance and gift tax in Germany: Reform potentials for tax revenue, efficiency and distribution. Public Sector Economics, 44(3), pp. 385-417. https://doi.org/10.3326/pse.44.3.5

12. Beznoska, M., Niehues, J. and Stockhausen, M., 2018. Die Vermögensverteilung im internationalen Vergleich. München: Vereinigung der Bayerischen Wirtschaft e. V.

13. Bø, E. E., Halvorsen, E. and Thoresen, T. O., 2019. Heterogeneity of the Carnegie effect. Journal of Human Resources, 54(3), pp. 726-759. https://doi. org/10.3368/jhr.54.3.0915.7366r 1

14. Bönke, T., van Werder, M. and Westermeier, C., 2017. How inheritances shape wealth distributions: An international comparison. Economics Letters, 159, pp. 217-220. https://doi.org/10.1016/j.econlet.2017.08.007

15. Boserup, S. H., Kopczuk, W. and Kreiner, T., 2016. The role of bequests in shaping wealth inequality: evidence from Danish wealth records. American Economic Review, 106(5), pp. 656-661. https://doi.org/10.3386/w21896

16. Brauns, B. and Schuler, K., 2016. Erbschaftssteuer - Verpasste Chance? Die Zeit, June 20, 2016. 
17. Bräutigam, R. [et al.], 2017. Länderindex Familienunternehmen-Erbschaftsteuer im internationalen Vergleich. München: Stiftung Familienunternehmen.

18. Brunetti, M. J., 2006. The estate tax and the demise of the family business. Journal of Public Economics, 90(10), pp. 1975-1993. https://doi.org/10.1016/j. jpubeco.2006.05.012

19. Brunner, J. K., 2014. Die Erbschaftsteuer-Bestandteil eines optimalen Steuersystems? Perspektiven der Wirtschaftspolitik, 15(3), pp. 199-218. https://doi. org/10.1515/pwp-2014-0019

20. Bundesministerium der Finanzen, 2012. Begünstigung des Unternehmensvermögens in der Erbschaftsteuer. Berlin: Bundesministerium der Finanzen.

21. Conway, K. S. and Rork, J. C., 2006. State "Death" Taxes and Elderly Migration - The Chicken or the Egg? National Tax Journal, 59(1), pp. 97-128. https://doi.org/10.17310/ntj.2006.1.05

22. Cremer, H. and Pestieau, P., 2011. The tax treatment of intergenerational wealth transfers. CESifo Economic Studies, 57(2), pp. 365-401.

23. Doorley, K. and Pestel, N., 2020. Labour supply after inheritances and the role of expectations. Oxford Bulletin of Economics and Statistics, 82(4), pp. 843863. https://doi.org/10.1111/obes. 12353

24. Elinder, M., Erixson, O. and Waldenström, D., 2018. Inheritance and wealth inequality: Evidence from population registers. Journal of Public Economics, 165, pp. 17-30. https://doi.org/10.1016/j.jpubeco.2018.06.012

25. EY, 2015. Wealth under the spotlight 2015 - How taxing the wealthy is changing. London: EY.

26. EY, 2016. Worldwide Estate and Inheritance Tax Guide. London: EY.

27. EY, 2020. Worldwide Estate and Inheritance Tax Guide. London: EY.

28. Fessler, P. and Schürz, M., 2018. Private wealth across European countries: the role of income, inheritance and the welfare state. Journal of Human Development and Capabilities, 19(4), pp. 521-549. https://doi.org/10.1080/194528 29.2018.1507422

29. Fessler, P. and Schürz, M., 2020. Inheritance and equal opportunity - it is the family that matters. Public Sector Economics, 44(4), pp. 463-482. https://doi. org/10.3326/pse.44.4.2

30. Henrekson, M. and Waldenström, D., 2016. Inheritance taxation in Sweden, 1885-2004: the role of ideology, family firms, and tax avoidance. The Economic History Review, 69(4), pp. 1228-1254. https://doi.org/10.1111/ehr.12280

31. Holtz-Eakin, D., Joulfaian, D. and Rosen, H. S., 1993. The Carnegie conjecture: Some empirical evidence. Quarterly Journal of Economics, 108, pp. 413-435. https://doi.org/10.2307/2118337

32. Houben, H. and Maiterth, R., 2011. Endangering of Businesses by the German Inheritance Tax? - An Empirical Analysis. Business Research, 4(1), pp. 32-46. https://doi.org/10.1007/bf03342725

33. Humer, S., 2014. Aufkommen von Erbschaftssteuern-Modellrechnung exemplarischer Tarife. Wirtschaft und Gesellschaft, 40(1), pp. 151-159. 
34. Humer, S., Moser, M. and Schnetzer, M., 2015. Socioeconomic structures of the Austrian wealth distribution. Empirica, 42(2), pp. 269-289. https://doi.org/ 10.1007/s10663-015-9293-3

35. Humer, S., Moser, M. and Schnetzer, M., 2016. Bequests and the Accumulation of Wealth in the Eurozone. INEQ Working Paper Series, No. 1.

36. Iara, A., 2015. Wealth distribution and taxation in EU Members. Brussels: Office for Official Publications of the European Communities.

37. Karagiannaki, E., 2017. The Impact of Inheritance of the Distribution of Wealth: Evidence from Great Britain. The Review of Income and Wealth, 63(2), pp. 394-408. https://doi.org/10.1111/roiw.12217

38. Kopczuk, W. and Slemrod, J., 2001. The Impact of the Estate Tax on the Wealth Accumulation and Avoidance Behavior of Donors. In: W. G. Gale, J. R. Hines and J. Slemrod, eds. Rethinking Estate and Gift Taxation. Brookings Institution, pp. 299-343. https://doi.org/10.3386/w7960

39. Kopczuk, W. and Slemrod, J., 2003. Dying to save taxes: Evidence from estate-tax returns on the death elasticity. Review of Economics and Statistics, 85(2), pp. 256-265. https://doi.org/10.1162/003465303765299783

40. Kopczuk, W., 2007. Bequest and tax planning: Evidence from estate tax returns. The Quarterly Journal of Economics, 122(4), pp. 1801-1854. https:// doi.org/10.1162/qjec.2007.122.4.1801

41. Kopczuk, W., 2013a. Incentive effects of inheritances and optimal estate taxation. The American Economic Review, 103(3), pp. 472-477. https://doi.org/10. 1257/aer.103.3.472

42. Kopczuk, W., 2013b. Taxation of Intergenerational Transfers and Wealth. In: J. Alan et al., eds. Handbook of Public Economics, 5, pp. 329-390. https://doi. org/10.1016/b978-0-444-53759-1.00006-6

43. Leitner, S., 2016. Drivers of wealth inequality in euro area countries: the effect of inheritance and gifts on household gross and net wealth distribution analysed by applying the Shapley value approach to decomposition. European Journal of Economics and Economic Policies, 13(1), pp. 114-136. https://doi. org/10.4337/ejeep.2016.01.10

44. Marterbauer, M. and Schürz, M., 2007. Der Streit um die Abschaffung der Erbschaftssteuer in Österreich. WISO, 30(1), pp. 32-52.

45. Nass-Schmidt, H. S. [et al.], 2011. Study on inheritance taxes in EU member states and possible mechanisms to resolve problems of double inheritance taxation in the EU. Brussels: European Commission Directorate General Taxation and Customs Union.

46. OECD, 2016. OECD Economic Surveys: Germany 2016. Paris: OECD. https://doi.org/10.1787/eco_surveys-deu-2016-en

47. OECD, 2018. The Role and Design of Net Wealth Taxes in the OECD. OECD Tax Policy Studies, No. 26. https://doi.org/10.1787/9789264290303-2-en

48. OECD, 2019. Economic Policy Reforms 2019: Going for Growth. Paris: OECD. https://doi.org/10.1787/aec5b059-en 
49. Schratzenstaller, M., 2013. Vermögensbezogene Steuern: Ansatzpunkte, internationaler Vergleich und Optionen für Deutschland. Wienna: Österreichisches Institut für Wirtschaftsforschung.

50. Schratzenstaller, M., 2015. Vermögensbezogene Steuern - die österreichische Perspektive. WISO, 38(1), pp. 34-62.

51. Sommer, E., 2017. Wealth Transfers and Tax Planning: Evidence for the German Bequest Tax. IZA Discussion Papers Series, No. 11120.

52. The Economist, 2017. The case of taxing death. The Economist, November $25^{\text {th }} 2017$.

53. Wiebe, T. and Fetzer, N., 2015. Die Neuregelung der Erbschaftssteuer für Familienunternehmen: Daten und Fakten zur Rolle des Betriebsvermögens. München: Stiftung Familienunternehmen.

54. Wolff, E. N. and Gittleman, M., 2014. Inheritances and the distribution of wealth or whatever happened to the great inheritance boom? The Journal of Economic Inequality, 12(4), pp. 439-468. https://doi.org/10.1007/s10888-013-9261-8 